\title{
Leptin and Leptin Receptor mRNA are Widely Expressed in Tumors of Adipocytic Differentiation
}

\author{
Andre M. Oliveira, M.D., Antonio G. Nascimento, M.D., Ricardo V. Lloyd, M.D., Ph.D. \\ Department of Laboratory Medicine and Pathology, Mayo Clinic and Mayo Foundation, Rochester, Minnesota
}

Adipose tissue is the principal source of leptin, a cytokine-like peptide with many biologic functions. Leptin binds to the leptin receptor, present in the hypothalamus and in many other tissues, and modulates energy balance and maintenance of body weight. The expression of leptin and leptin receptor in tumors of adipocytic differentiation has not been previously examined. Because normal adipose tissue is the principal source of leptin and expresses leptin receptor, we hypothesized that tumors of adipose tissue differentiation may also express leptin and/or the long functional form of the leptin receptor (OB-Rb).

Leptin and OB-Rb were analyzed by immunohistochemistry, in situ hybridization, RT-PCR, and western blotting in 21 lipomas, 2 hibernomas, and 16 liposarcomas. Immunostaining and in situ hybridization showed leptin and OB-Rb mRNA expression in all cases of lipomas, hibernomas, and liposarcomas, including dedifferentiated and pleomorphic liposarcomas. RT-PCR analysis showed leptin and OB-Rb mRNA in both lipomas $(n=5)$ and liposarcomas $(n=$ 5). Western blotting identified the $16 \mathrm{kDa}$ leptin protein in a lipoma and a liposarcoma. No important difference in the expression of leptin and OB-Rb mRNA was found between lipomas and liposarcomas, although the level of leptin protein was higher in a lipoma than a liposarcoma by western blotting.

These results show for the first time that leptin and OB-Rb mRNA are expressed in lipomas, hibernomas, and liposarcomas. The presence of leptin and its receptor may provide new insights into the pathobiology of these tumors.

KEY WORDS: Hibernoma, Leptin, Leptin receptor (OB-Rb), Lipoma, Liposarcoma.

Mod Pathol 2001;14(6):549-555

Copyright $\odot 2001$ by The United States and Canadian Academy of Pathology, Inc.

VOL. 14, NO. 6, P. 549, 2001 Printed in the U.S.A

Date of acceptance: November 15, 2000.

Address reprint requests to: Ricardo V. Lloyd, M.D., Ph.D., Department of

Laboratory Medicine and Pathology, Mayo Clinic, 200 First Street SW,

Rochester, MN 55905; e-mail: lloyd.ricardo@mayo.edu; fax: 507-284-1599.
Adipose tissue is the main source of leptin, the product of the ob gene (1) located on human chromosome $7(2,3)$. Multiple biologic roles have been attributed to leptin, which include maintenance of body weight, food intake, body temperature, development of the reproductive system, bone remodeling, angiogenesis, immunomodulation, and a variety of endocrine functions (4-11). Leptin binds to the leptin receptor (OB-R), the product of the $\mathrm{db}$ gene (12) located on human chromosome 1 (13). Five different isoforms of this receptor were identified $(12,14)$ and they are present in a variety of human tissues, with higher expression in the hypothalamus, heart, liver, small bowel, prostate, and ovary (12-14). The long functional form of the OB-R, OB-Rb, is expressed mainly in the hypothalamus $(10,11,14-16)$ and the leptin binding to this receptor inhibits food intake and stimulates energy expenditure through modulatory effects on the activity of many neurotransmitters and neuropeptides (5).

The presence of leptin and $\mathrm{OB}-\mathrm{Rb}$ has been shown in normal white and brown tissue (17-23). However, leptin and OB-Rb have not been examined in neoplasms with white and brown adipose tissue differentiation, such as lipomas, hibernomas, and liposarcomas.

We examined leptin and OB-Rb mRNA expression in neoplasms of adipocytic differentiation to gain new insights into the understanding of the pathobiology of these tumors.

\section{MATERIALS AND METHODS}

\section{Clinicopathologic Data}

Twenty-one lipomas, two hibernomas, and 16 liposarcomas cases were retrieved from the Mayo Clinic Tissue Registry and reviewed histologically for diagnostic confirmation. An average of five hematoxylin-eosin slides were available for each case (range, 1 to 18). Clinicopathologic data were studied in all cases and are summarized in Table 1. History of obesity and hyperlipidemia were also reviewed. The characterization of obesity and hy- 
TABLE 1. Clinicopathologic Features and Leptin and Leptin Receptor Expression in Adipose Tissue Tumors

\begin{tabular}{|c|c|c|c|c|c|c|c|c|c|}
\hline Case & Age & Sex & Diagnosis & Location & Obesity & Hyperlipidemia & $\begin{array}{l}\text { Size } \\
(\mathrm{cm})\end{array}$ & $\begin{array}{l}\text { Leptin } \\
\text { Expression } \\
\text { (IH/ISH) }\end{array}$ & $\begin{array}{l}\text { Leptin Receptor } \\
\text { Expression } \\
\text { (ISH) }\end{array}$ \\
\hline 1 & 45 & $\mathrm{~F}$ & Lipoma & Flank & $\mathrm{Y}$ & $\mathrm{Y}$ & 9 & $\mathrm{f}+/ \mathrm{d}++$ & $\mathrm{d}+++$ \\
\hline 2 & 68 & M & Lipoma & Back & $\mathrm{n} / \mathrm{a}$ & $\mathrm{n} / \mathrm{a}$ & $\mathrm{n} / \mathrm{a}$ & $0 / \mathrm{d}+$ & $\mathrm{d}+++$ \\
\hline 3 & 73 & M & Lipoma & Shoulder & $\mathrm{Y}$ & $\mathrm{Y}$ & 4.5 & $\mathrm{f}+/ \mathrm{f}+++$ & $\mathrm{d}+++$ \\
\hline 4 & 32 & $\mathrm{~F}$ & Lipoma & Vulva & $\mathrm{n} / \mathrm{a}$ & $\mathrm{n} / \mathrm{a}$ & 5 & $\mathrm{f}+/ \mathrm{d}++$ & $\mathrm{d}+++$ \\
\hline 5 & 36 & $\mathrm{M}$ & Lipoma & Flank & $\mathrm{N}$ & $\mathrm{n} / \mathrm{a}$ & 3 & $\mathrm{f}+/ \mathrm{d}+++$ & $\mathrm{d}+++$ \\
\hline 6 & 66 & $\mathrm{~F}$ & Lipoma & Chest & $\mathrm{N}$ & $\mathrm{N}$ & 11 & $\mathrm{f}+/ \mathrm{d}++$ & $\mathrm{d}+++$ \\
\hline 7 & 39 & $\mathrm{~F}$ & Lipoma & Shoulder & $\mathrm{n} / \mathrm{a}$ & $\mathrm{n} / \mathrm{a}$ & 5.5 & $\mathrm{f}+/ \mathrm{d}+$ & $\mathrm{d}+++$ \\
\hline 8 & 74 & $\mathrm{M}$ & Lipoma & Neck & $\mathrm{n} / \mathrm{a}$ & $\mathrm{Y}$ & 3.5 & $\mathrm{f}+/ \mathrm{d}+$ & $\mathrm{d}+++$ \\
\hline 9 & 23 & $\mathrm{M}$ & Lipoma & Thigh & $\mathrm{n} / \mathrm{a}$ & $\mathrm{n} / \mathrm{a}$ & 27 & $\mathrm{f}+/ \mathrm{d}++$ & $\mathrm{d}++$ \\
\hline 10 & 39 & $\mathrm{~F}$ & Lipoma & Flank & $\mathrm{n} / \mathrm{a}$ & $\mathrm{n} / \mathrm{a}$ & $\mathrm{n} / \mathrm{a}$ & $\mathrm{f}+/ \mathrm{d}+$ & $\mathrm{d}++$ \\
\hline 11 & 21 & $\mathrm{~F}$ & Angiolipoma & Arm & $\mathrm{N}$ & $\mathrm{N}$ & 1 & $\mathrm{f}+/ \mathrm{d}+$ & $\mathrm{d}+++$ \\
\hline 12 & 33 & M & Angiolipoma & Thigh & $\mathrm{Y}$ & $\mathrm{N}$ & 3 & $\mathrm{f}+/ \mathrm{d}+$ & $\mathrm{d}+++$ \\
\hline 13 & 46 & M & Angiolipoma & Flank & $\mathrm{n} / \mathrm{a}$ & $\mathrm{n} / \mathrm{a}$ & 1.5 & $\mathrm{f}+/ \mathrm{d}++$ & $\mathrm{d}+++$ \\
\hline 14 & 85 & M & Angiolipoma & Back & $\mathrm{N}$ & $\mathrm{Y}$ & 3.5 & $\mathrm{f}+/ \mathrm{d}+$ & $\mathrm{d}+++$ \\
\hline 15 & 29 & $\mathrm{~F}$ & Angiolipoma & Arm & $\mathrm{N}$ & $\mathrm{Y}$ & 0.8 & $\mathrm{f}+/ \mathrm{f}++$ & $\mathrm{d}++$ \\
\hline 16 & 44 & M & Spindle Cell lipoma & Neck & $\mathrm{Y}$ & $\mathrm{Y}$ & 1.2 & $\mathrm{f}+/ \mathrm{d}+$ & $\mathrm{d}++$ \\
\hline 17 & 63 & $\mathrm{M}$ & Spindle Cell lipoma & Neck & $\mathrm{Y}$ & $\mathrm{Y}$ & 5 & $\mathrm{f}+/ \mathrm{d}++$ & $\mathrm{d}++$ \\
\hline 18 & 76 & M & Spindle Cell lipoma & Back & $\mathrm{N}$ & $\mathrm{n} / \mathrm{a}$ & 7 & $\mathrm{f}+/ \mathrm{d}++$ & $\mathrm{d}+++$ \\
\hline 19 & 68 & M & Spindle Cell lipoma & Neck & $\mathrm{Y}$ & $\mathrm{n} / \mathrm{a}$ & 1.5 & $\mathrm{f}+/ \mathrm{d}+$ & $\mathrm{f}++$ \\
\hline 20 & 60 & M & Spindle Cell lipoma & Back & $\mathrm{Y}$ & $\mathrm{Y}$ & 0.5 & $\mathrm{f}+/ \mathrm{d}+$ & $\mathrm{d}+++$ \\
\hline 21 & 53 & $\mathrm{~F}$ & Pleomorphic lipoma & Breast & $\mathrm{n} / \mathrm{a}$ & $\mathrm{n} / \mathrm{a}$ & $\mathrm{n} / \mathrm{a}$ & $\mathrm{d}+++/ \mathrm{d}+++$ & $\mathrm{d}+++$ \\
\hline 22 & 37 & M & Hibernoma & Back & $\mathrm{n} / \mathrm{a}$ & $\mathrm{n} / \mathrm{a}$ & 8.5 & $\mathrm{~d}+++/ \mathrm{d}+++$ & $\mathrm{d}+++$ \\
\hline 23 & 65 & M & Hibernoma & Back & $\mathrm{Y}$ & $\mathrm{Y}$ & 13 & $\mathrm{~d}+++/ \mathrm{d}+++$ & $\mathrm{d}+++$ \\
\hline 24 & 64 & M & Well-differentiated liposarcoma & Retroperitoneum & $\mathrm{N}$ & $\mathrm{Y}$ & 40 & $\mathrm{~d}+++/ \mathrm{d}+++$ & $\mathrm{d}++$ \\
\hline 25 & 76 & M & Well-differentiated liposarcoma & Retroperitoneum & $\mathrm{Y}$ & $\mathrm{Y}$ & 12 & $\mathrm{~d}+++/ \mathrm{d}+++$ & $\mathrm{d}++$ \\
\hline 26 & 67 & M & Well-differentiated liposarcoma & Paratesticular area & $\mathrm{N}$ & $\mathrm{N}$ & 8 & $\mathrm{~d}+++/ \mathrm{d}+++$ & $\mathrm{d}++$ \\
\hline 27 & 68 & M & Well-differentiated liposarcoma & Thigh & $\mathrm{Y}$ & $\mathrm{n} / \mathrm{a}$ & 40 & $\mathrm{~d}+++/ \mathrm{d}+++$ & $\mathrm{d}+++$ \\
\hline 28 & 40 & $\mathrm{~F}$ & Well-differentiated liposarcoma & Retroperitoneum & $\mathrm{n} / \mathrm{a}$ & $\mathrm{n} / \mathrm{a}$ & $\mathrm{n} / \mathrm{a}$ & $\mathrm{d}++/ \mathrm{d}+++$ & $\mathrm{d}+++$ \\
\hline 29 & 63 & $\mathrm{~F}$ & Well-differentiated liposarcoma & Retroperitoneum & $\mathrm{N}$ & $\mathrm{Y}$ & 22 & $\mathrm{~d}++/ \mathrm{d}++$ & $\mathrm{d}+++$ \\
\hline 30 & 48 & $\mathrm{M}$ & Well-differentiated liposarcoma & Retroperitoneum & $\mathrm{n} / \mathrm{a}$ & $\mathrm{N}$ & 18 & $\mathrm{~d}++/ \mathrm{d}++$ & $\mathrm{d}+++$ \\
\hline 31 & 51 & $\mathrm{~F}$ & Dedifferentiated liposarcoma & Retroperitoneum & $\mathrm{N}$ & $\mathrm{N}$ & 11 & $\mathrm{~d}+++/ \mathrm{d}+++$ & $\mathrm{d}+++$ \\
\hline 32 & 68 & $\mathrm{~F}$ & Dedifferentiated liposarcoma & Retroperitoneum & $\mathrm{N}$ & $\mathrm{N}$ & 24 & $\mathrm{~d}+++/ \mathrm{d}+++$ & $\mathrm{d}++$ \\
\hline 33 & 40 & $\mathrm{~F}$ & Dedifferentiated liposarcoma & Retroperitoneum & $\mathrm{N}$ & $\mathrm{N}$ & 20 & $\mathrm{~d}++/ \mathrm{d}+++$ & $\mathrm{d}++$ \\
\hline 34 & 38 & $\mathrm{~F}$ & Myxoid/Round Cell liposarcoma & Thigh & $\mathrm{N}$ & $\mathrm{N}$ & 10 & $\mathrm{~d}++/ \mathrm{d}+++$ & $\mathrm{d}++$ \\
\hline 35 & 39 & M & Myxoid/Round Cell liposarcoma & Shoulder & $\mathrm{N}$ & $\mathrm{N}$ & 11 & $\mathrm{~d}+/ \mathrm{d}+++$ & $\mathrm{d}+++$ \\
\hline 36 & 51 & M & Myxoid/Round Cell liposarcoma & Thigh & $\mathrm{N}$ & $\mathrm{n} / \mathrm{a}$ & 11 & $\mathrm{~d}++/ \mathrm{d}+++$ & $\mathrm{d}++$ \\
\hline 37 & 49 & M & Myxoid/Round Cell liposarcoma & Thigh & $\mathrm{N}$ & $\mathrm{n} / \mathrm{a}$ & 15 & $\mathrm{~d}++/ \mathrm{d}+++$ & $\mathrm{d}++$ \\
\hline 38 & 42 & M & Myxoid/Round Cell liposarcoma & Leg & $\mathrm{Y}$ & $\mathrm{Y}$ & 6 & $\mathrm{~d}++/ \mathrm{d}+++$ & $\mathrm{d}++$ \\
\hline 39 & 84 & M & Pleomorphic liposarcoma & Thigh & $\mathrm{Y}$ & $\mathrm{N}$ & 4.5 & $\mathrm{~d}++/ \mathrm{d}+++$ & $\mathrm{d}+++$ \\
\hline
\end{tabular}

Y, present; N, absent; n/a, not available; IH, immunohistochemistry; ISH, in situ hybridization; f, focal; d, diffuse; + , mild; ++ , moderate; +++ , intense.

perlipidemia were made according to established criteria $(24,25)$.

The 21 lipomas were classified as ordinary type ( $n=$ $10)$, angiolipoma $(n=5)$, spindle cell $(n=5)$, and pleomorphic $(n=1)$. The 16 liposarcomas were classified as well-differentiated ( $n=7)$, well-differentiated with areas of dedifferentiation $(n=3)$, myxoid/round cell ( $n$ $=5)$, and pleomorphic $(n=1)$. Two cases of hibernoma were also examined.

\section{Immunohistochemistry}

Paraffin-embedded, formalin-fixed, archival tissues (5 $\mu \mathrm{m}$-thick slides) from all tumors were analyzed for leptin expression with a monoclonal antibody from Sigma Chemical Co. (St Louis, MO) at a dilution of 1:250 using the avidin-biotin-peroxidase method (26). Antigen retrieval was done with microwave treatment for 5 minutes in $0.1 \mathrm{~mol} / \mathrm{L} \mathrm{ci}$ trate buffer, $\mathrm{pH}$ 6.0. Five samples each from normal subcutaneous and retroperitoneal adipose tissue and normal anterior pituitary gland tissue were used as positive controls for the immunohistochemical analysis. Staining intensity was graded as 0 (none), $1+$ (mild), $2+$ (moderate), +3 (intense), and considered focal when less than $25 \%$ of the cells were stained.

\section{Western Blot Analysis}

Western blot analysis was performed as previously reported method (27) using proteins extracted from frozen tissue from a lipoma and a liposarcoma. One-dimensional sodium dodecyl sulfate-polyacrylamide gel electrophoresis was performed with a ready-to-use 10 to $20 \%$ gradient gel using the discontinuous buffer system of Laemmli (Bio-Rad Laboratories, Richmond, CA). The electrophoresed proteins were transferred to a polyvinyllidene difluoride membrane and subjected to immunoblot analysis with monoclonal antibodies to leptin as previously reported (27). Densitometric 
analysis of the leptin bands was done as previously described (28).

\section{In Situ Hybridization (ISH)}

Paraffin-embedded, formalin-fixed, archival tissues (5 $\mu \mathrm{m}$-thick slides) from all tumors were used for ISH. Five samples each from normal subcutaneous and retroperitoneal adipose tissue and normal anterior pituitary gland tissue were used as positive controls for the ISH analysis. The human leptin (OB; obtained by RT-PCR from normal fat total RNA) and the functional form of the leptin receptor (OB-Rb) complementary DNA (obtained from Eli Lilly \& Co,, Indianapolis, IN) were cloned into pCRII-TOPO (Invitrogen, Carlsbad, CA) and linearized with BamHI or ApaI. Riboprobes were generated by in vitro transcription reaction and digoxigenin 11-UTP (Boehringer Mannheim, Indianapolis, IN) labeling with T7 (antisense) and SP6 (sense) RNA polymerase for OB and OB-Rb (Promega Corp., Madison, WI). The labeled probes were digested with deoxyribonuclease, extracted with phenol/chloroform, and precipitated with ethanol. ISH signals were detected by the antidigoxigenin AP (1:200 dilution; Boehringer Mannheim) and nitroblue tetrazolium/5-bromo-4-chloro-3-indolylphosphate system $(27,28)$.

\section{RT-PCR}

Total RNA was extracted from available frozen or fresh tissue in five lipomas and five liposarcomas using the TRIzol reagent kit (Life Technologies, Inc., Gaithersburg, MD) and used for the identification of leptin and OB-Rb messenger RNAs by RT-PCR. The housekeeping genes hypoxanthine phosphoribosyl transferase and glyceraldehyde-3-phosphate dehydrogenase were used as internal positive controls. RT-PCR was performed according to previously described methods (27). Thirty cycles of PCR amplification with $57^{\circ} \mathrm{C}$ annealing temperature were used for $\mathrm{OB}-\mathrm{Rb}$ and 40 cycles with $55^{\circ} \mathrm{C}$ annealing temperature were used for leptin. PCR products were analyzed by $2 \%$ agarose gel electrophoresis with ethidium bromide staining and Southern hybridization. The sequences of primers and hybridization probes for leptin and OB-Rb were previously reported (27). Densitometric analysis of the bands for Southern hybridization was done as previously described $(27,28)$.

\section{RESULTS}

\section{Clinical Features}

The clinicopathologic data for the 39 tumors are summarized in Table 1. In the lipoma group (including hibernomas), the mean age at diagnosis was 51 years (range, 21 to 85 years). Thirty-five percent of patients were female. Three patients had a history of two or more tumors (Cases 5, 11, and 14). Eight patients were obese, and nine had hyperlipidemia. In the liposarcoma group, the mean age was 56 years (range, 40 to 84 years). The female sex was affected in $31 \%$ of the cases. History of obesity or hyperlipidemia was found in six patients

\section{Immunohistochemistry}

\section{Leptin Expression in Lipomas and Hibernomas}

All histologic subtypes of lipoma showed cytoplasmic immunoreactivity for leptin (Fig. 1A), except for one case that was negative (Case 2). The pattern of immunoreactivity was usually focal in most ordinary lipomas, angiolipomas, and spindle cell lipomas. Diffuse immunoreactivity was present in the hibernomas (Fig. 1B) and the pleomorphic lipoma. Both mature adipocytes and spindle cells expressed leptin in spindle cell lipoma. In pleomorphic lipoma, mature adipocytes and the few lipoblasts also expressed leptin. Immunoreactivity for leptin was diffuse and present in the large granular cells, lipoblast-like cells, and mature adipocytes of hibernomas (Fig. 1B). Endothelial cells and occasional lymphocytes also showed focal immunoreactivy for leptin. Fibroblasts and other connective tissue cells were negative for leptin.

\section{Leptin Expression in Liposarcomas}

Leptin was expressed in a diffuse cytoplasmic pattern in all subtypes of liposarcoma. Both mature adipocytes and lipoblasts expressed leptin in welldifferentiated liposarcoma (Fig. 1, C-D). Areas of dedifferentiation with a high-grade morphology were present in three of these cases, and the pleomorphic cells expressed leptin. The lipoblasts and poorly differentiated cells of pleomorphic liposarcoma also expressed leptin. In myxoid and round cell liposarcomas, lipoblasts, primitive stellateshaped, and round cells were positive for leptin.

\section{Western Blotting}

Western blotting analysis identified the $16 \mathrm{kDa}$ leptin protein in a lipoma and a liposarcoma (Fig. 2). Densitometric analysis showed that the lipoma expressed more leptin protein than the liposarcoma when the results were normalized with $\beta$-actin (data not shown).

\section{In Situ Hybridization}

Leptin and OB-Rb mRNA were expressed in a diffuse cytoplasmic pattern in almost all cases of lipomas, hibernomas, and liposarcomas (Fig. 3). Nonspecific nuclear staining was observed in hiber- 


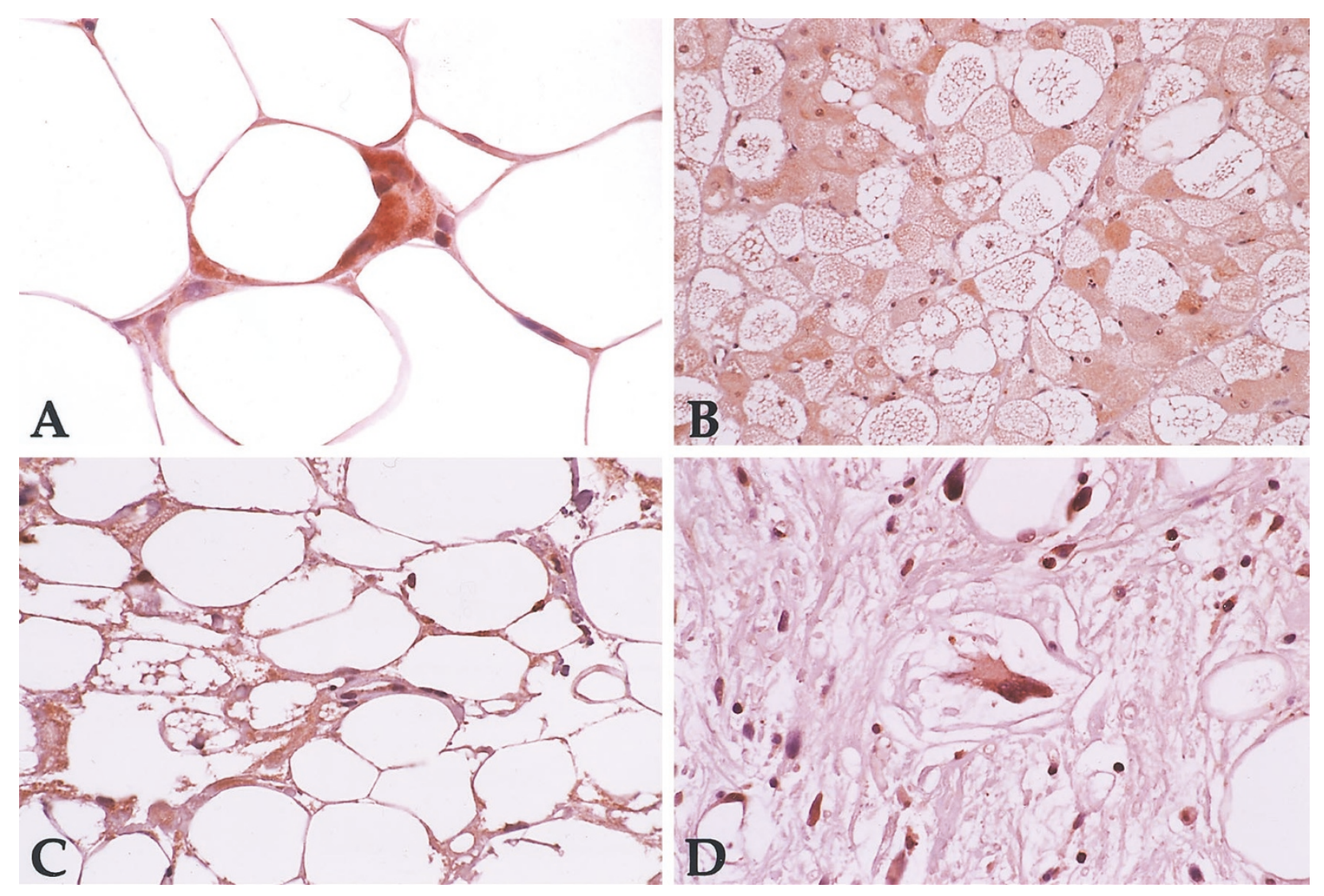

FIGURE 1. Cytoplasmic immunoreactivity for leptin in lipoma (A), hibernoma (B), and well-differentiated liposarcoma (C and D). Nonspecific nuclear/nucleolar staining was observed in some cells, especially in the hibernoma (B). Except for one lipoma (Table 1), all benign and malignant tumors expressed leptin.

nomas and liposarcomas. No important difference in staining intensity was observed between benign and malignant tumors. In addition, no difference in staining intensity was observed among different histologic subtypes of lipomas and liposarcoma. Leptin and OB-Rb mRNA were observed in all cell types in hibernomas and were focally present in endothelial cells. Fibroblasts and other connective tissue cells were negative for both leptin and OB-Rb mRNA.

Immunohistochemistry and ISH analyses showed no important differences in the expression of leptin and OB-Rb mRNA between benign and malignant tumors in obese and lean patients, hyperlipidemic and normolipidemic patients, and male and female patients.

\section{RT-PCR}

Leptin mRNA expression was detected in normal adipose tissue, lipomas, and liposarcomas. OB-Rb mRNA was detected in all five lipomas and five liposarcomas (Fig. 4). The expression of OB-Rb mRNA was low in one lipoma (Case 10), but a reliable history of obesity and hyperlipidemia was not available. Two liposarcomas expressed OB-Rb mRNA in very low concentrations (Cases 29 and
38), and both patients had a history of hyperlipidemia or obesity. No important difference in the expression of leptin and OB-Rb mRNA was found between lipomas and liposarcomas when the samples were normalized with hypoxanthine phosphoribosyl transferase and analyzed by densitometry (data not shown).

\section{DISCUSSION}

Leptin is a $16 \mathrm{kDa}$ peptidic hormone mainly synthesized and secreted by the adipose tissue. In the peripheral blood circulation, plasma levels of leptin correlate very well with total body adipose tissue mass (29). Higher plasma concentrations of leptin are often found in obese individuals and tend to decrease after weight loss (29). After crossing the blood-brain barrier by a transport system not completely elucidated $(30,31)$, leptin binds to the leptin receptor (OB-Rb) in the hypothalamus and appears to activate the Janus protein-tyrosine kinase and Signal Transducers and Activators of Transcription (STAT) pathway (32). In the hypothalamus, leptin has stimulatory effects on corticotropin-releasing hormone, pro-opiomelanocortin, thyrotropin-releasing hormone, and cocaine- and amphetamine-regulated transcript, and inhibitory effects on neuropeptide $\mathrm{Y}$ and agouti-related protein $(5,7)$. 
$\begin{array}{llllllllll}1 & 2 & 3 & 4 & 6 & 7 & 8 & 9 & 1011 & 12 \\ \text { bp }\end{array}$
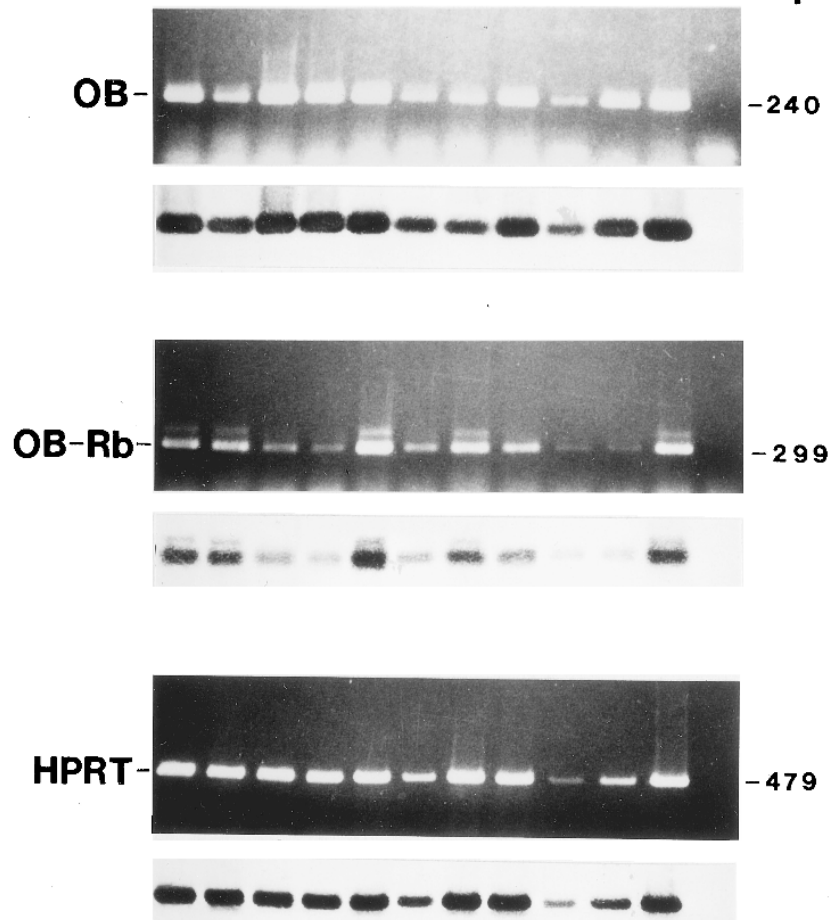

FIGURE 2. Expression of leptin and the long form of the leptin receptor (OB-Rb) in lipomas and liposarcomas by RT-PCR. Top panel, leptin; middle panel, leptin receptor (OB-Rb), bottom panel, hypoxanthine phosphoribosyl transferase (HPRT) used to check the quality of the mRNA. Lanes 1 through 5, lipomas (Cases 6 to 10). Lanes 6-10, liposarcomas (Cases 6, 7, 9, 15, and 16). Lane 11, normal adipose tissue used as a positive control. Lane 12, negative RT control. The lower portion of each panel shows the Southern hybridization results using internal probes for each primer set as previously reported (27). The sizes of the amplified products are shown on the right.

We demonstrated for the first time that tumors of adipocytic differentiation, similar to normal adipose tissue, express leptin and OB-Rb mRNA. Interestingly, leptin expression was unusually focal in mature adipocytes in lipomas and more diffuse in more primitive cells and lipoblasts. This may be related to the fact that the immunohistochemical staining was more difficult to interpret because of the cytoplasmic displacement caused by the large amount of lipid in more mature adipocytes. However, this pattern of staining was less prominent with ISH for leptin mRNA. In the latter, a more distinct cytoplasmic staining was observed.

Leptin and OB-Rb have been found in both normal white and brown adipose tissue $(15,17-23)$. However, leptin expression in brown adipose tissue has been somewhat controversial $(19,20,33-35)$. Our results showed that benign white and brown adipose tumors both expressed leptin protein, leptin mRNA, and OB-Rb mRNA.

Leptin expression is not restricted to adipose tissue because mammary cells, placenta, gastric epithelium, and pituitary all express leptin (27). We also observed leptin expression in some endothelial cells and lymphocytes, but not in fibroblasts in this study.

The ISH analysis of leptin and Ob-Rb mRNA showed nuclear staining in some tumors. This finding was interpreted as nonspecific because it is sometimes seen in ISH studies. The cause and significance of this finding is unknown at this time.

The regulation of leptin production in adipose tissue has been studied extensively. Experiments in rats showed direct effects of leptin on the adipose tissue, with an increased rate of insulin-dependent glucose utilization and lipolysis in white and brown adipose tissue after peripheral administration of leptin (36). Leptin binding to the OB-Rb also stimulated the expression of mRNA for malic enzyme and lipoprotein lipase in brown adipocyte cultures of lean $(\mathrm{Fa} / \mathrm{fa})$ rats, but not in brown adipocyte cultures from obese Zucker (fa/fa) rats, which have an inactivating mutation in the OB-Rb gene. Similar results were observed for leptin induction of STAT activity. After leptin administration, STAT activity was increased in both white and brown adipose tissue cultures but not in brown adipose tissue cultures of obese Zucker (fa/fa) rats (36). These results suggest that leptin has a direct autocrine and paracrine effect on normal adipocytes. Because we showed that leptin and OB-Rb mRNA are expressed in tumors of white and brown adipocytic differentiation, it is conceivable that the same autocrine and paracrine effects might be present in these tumors. However, further studies should be performed to examine these possibilities.

Fatty acids present in mature adipocytes in lipomas, and adipocytes and lipoblasts in liposarcomas seem to be unavailable for the general metabolism (37-39). This fact is well exemplified with the observation that the volume of these tumors does not change significantly during weight loss (37). In addition, the tumor volume of disseminated liposarcomas does not appear to diminish in cachectic patients. In contrast, lipoma volume increases during rapid weight gain (37). The underlying causes for these observations are still unknown and intrinsic alterations in the biochemical pathways of the neoplastic cells might be present (39-41). The presence of both leptin and OB-Rb mRNA expression almost excludes the possibility that changes in the leptin receptor between normal adipose tissue and lipomas and liposarcomas can account for these differences.

An important differential expression of leptin and OB-Rb mRNA with respect to the obesity and hyperlipidemia status or sex of the patients was not found on our series. However, due to the small number of cases, statistical analysis could not be performed. These findings suggest that leptin and OB-Rb mRNA expression in adipose tumors is probably independent of or at least not 

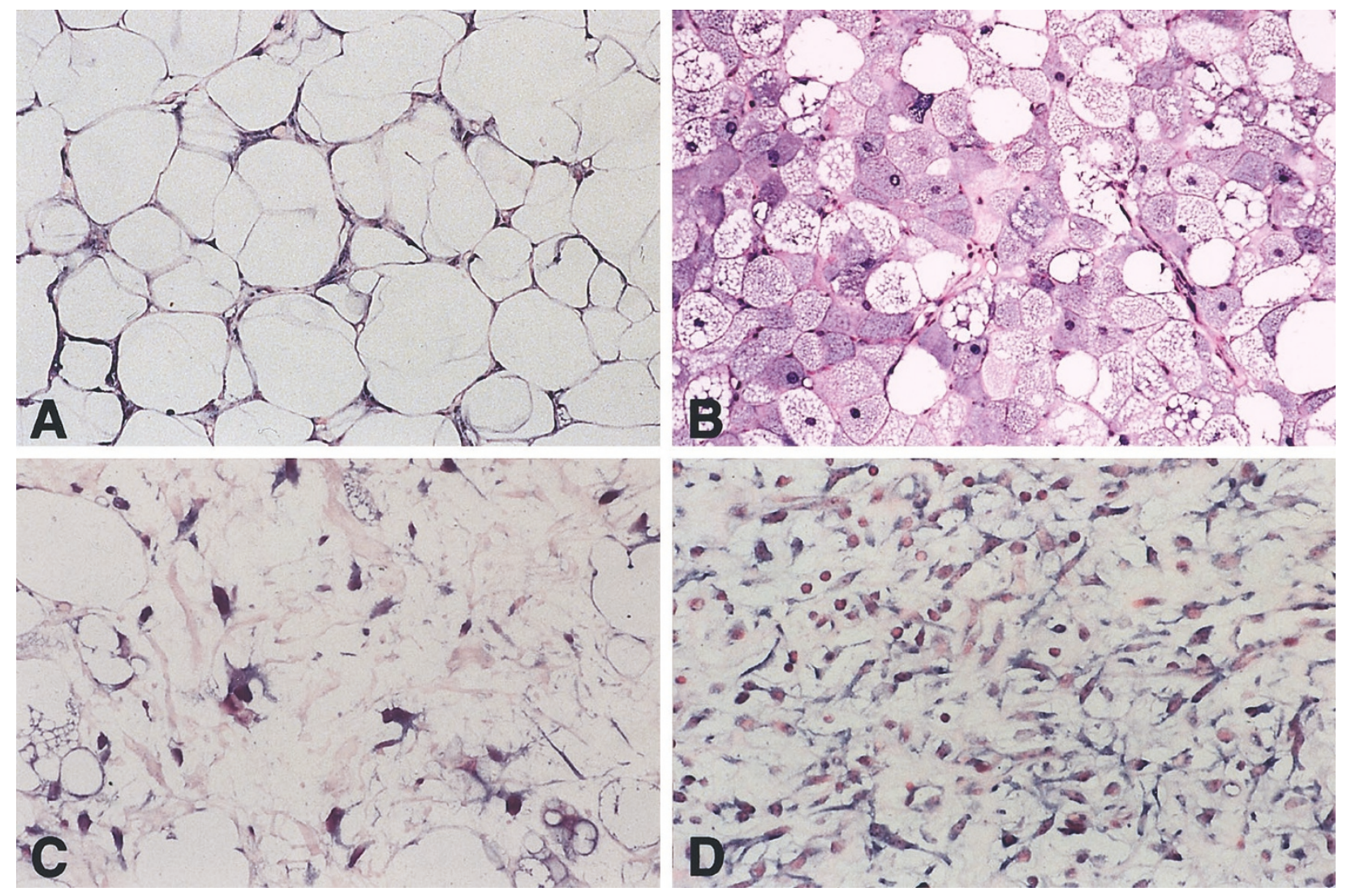

FIGURE 3. In situ hybridization showed leptin mRNA and leptin receptor mRNA in all lipomas, hibernomas, and liposarcomas. Leptin mRNA expression in lipoma (A) and hibernoma (B). Leptin receptor mRNA expression in well-differentiated (C) and myxoid liposarcoma (D). Nonspecific nuclear/nucleolar staining for leptin and OB-Rb mRNA was seen in some cells of liposarcoma and hibernoma (blue, positive signal; red, nuclear fast red counterstain).

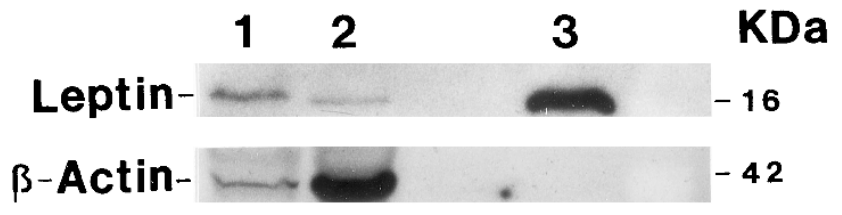

FIGURE 4. Western blotting to localize leptin in a lipoma and a liposarcoma. Top panel (lane 1), lipoma; (lane 2), liposarcoma; (lane 3), $50 \mathrm{ng}$ of purified leptin protein used as a positive control; $50 \mu \mathrm{g}$ of protein was used in lanes 1 and 2 . The bottom panel shows the result of blotting with $\beta$-actin to normalize for equal loading of the gel. The molecular sizes of the bands are indicated on the right.

markedly influenced by serum levels of leptin. In this regard, it is possible that (1) a dysfunctional autocrine or paracrine loop might be present in these tumors, which would contribute to their metabolic refractoriness; and (2) a paraneoplastic hyperleptinemia may exist in large or multiple tumors, such as in patients with large retroperitoneal liposarcomas or in patients with lipomatosis. Our findings also suggest that the leptin receptor could possibly be used as a potential target for drug or hormone therapy in unresectable or metastatic liposarcomas.

Despite the presence of leptin or leptin receptor in adipose tissue tumors, the use of these markers as diagnostic tools for the identification of tumors of adipocytic differentiation should be viewed with caution because other normal cell types and neoplasms also express leptin or leptin receptor (27).

In summary, we demonstrated for the first time that lipomas, hibernomas, and liposarcomas express leptin and leptin receptor. These findings should provide new insights into the understanding of the pathobiology of these tumors.

\section{REFERENCES}

1. Zhang Y, Proenca R, Maffei M, Barone M, Leopold L, Friedman JM. Positional cloning of the mouse obese gene and its human homologue. Nature 1994;372:425-32.

2. Clement K, Garner C, Hager J, Philippi A, LeDuc C, Carey A, et al. Indication for linkage of the human $\mathrm{OB}$ gene region with extreme obesity. Diabetes 1996;45:687-90.

3. Friedman JM, Leibel RL, Bahary N. Molecular mapping of obesity genes. Mamm Genome 1991;1:130-44.

4. Pelleymounter MA, Cullen MJ, Baker MB, Hecht R, Winters $\mathrm{D}$, Boone T, et al. Effects of the obese gene product on body weight regulation in ob/ob mice. Science 1995;269:540-3.

5. Friedman JM, Halaas JL. Leptin and the regulation of body weight in mammals. Nature 1998;395:763-70.

6. Considine RV, Caro JF. Leptin and the regulation of body weight. Int J Biochem Cell Biol 1997;29:1255-72. 
7. Stephens TW, Caro JF. To be lean or not to be lean. Is leptin the answer? Exp Clin Endocrinol Diabetes 1998;106:1-15.

8. Strobel A, Issad T, Camoin L, Ozata M, Strosberg AD. A leptin missense mutation associated with hypogonadism and morbid obesity. Nat Genet 1998;18:213-5.

9. Thomas T, Gori F, Khosla S, Jensen MD, Burguera B, Riggs BL. Leptin acts on human marrow stromal cells to enhance differentiation to osteoblasts and to inhibit differentiation to adipocytes. Endocrinology 1999;140:1630-8.

10. Lord GM, Matarese G, Howard JK, Baker RJ, Bloom SR, Lechler RI. Leptin modulates the T-cell immune response and reverses starvation-induced immunosuppression. Nature 1998;394:897-901.

11. Sierra-Honigmann MR, Nath AK, Murakami C, GarciaCardena G, Papapetropoulos A, Sessa WC, et al. Biological action of leptin as an angiogenic factor. Science 1998;281: 1683-6.

12. Tartaglia LA, Dembski M, Weng X, Deng N, Culpepper J, Devos R, et al. Identification and expression cloning of a leptin receptor, OB-R. Cell 1995;83:1263-71.

13. Cioffi JA, Shafer AW, Zupancic TJ, Smith-Gbur J, Mikhail A, Platika D, et al. Novel B219/OB receptor isoforms: possible role of leptin in hematopoiesis and reproduction. Nat Med 1996;2:585-9.

14. Lee GH, Proenca R, Montez JM, Carroll KM, Darvishzadeh JG, Lee JI, et al. Abnormal splicing of the leptin receptor in diabetic mice. Nature 1996;379:632-5.

15. Ghilardi N, Ziegler S, Wiestner A, Stoffel R, Heim MH, Skoda RC. Defective STAT signaling by the leptin receptor in diabetic mice. Proc Natl Acad Sci USA 1996;93:6231-5.

16. Kutoh E, Boss O, Levasseur F, Giacobino JP. Quantification of the full length leptin receptor (OB-Rb) in human brown and white adipose tissue. Life Sci 1998;62:445-51.

17. Masuzaki H, Ogawa Y, Isse N, Satoh N, Okazaki T, Shigemoto $\mathrm{M}$, et al. Human obese gene expression. Adipocyte-specific expression and regional differences in the adipose tissue. Diabetes 1995;44:855-8.

18. Hamilton BS, Paglia D, Kwan AY, Deitel M. Increased obese mRNA expression in omental fat cells from massively obese humans. Nat Med 1995;1:953-6.

19. Maffei M, Fei H, Lee GH, Dani C, Leroy P, Zhang Y, et al. Increased expression in adipocytes of ob RNA in mice with lesions of the hypothalamus and with mutations at the $\mathrm{db}$ locus. Proc Natl Acad Sci USA 1995;92:6957-60.

20. Moinat M, Deng C, Muzzin P, Assimacopoulos-Jeannet F, Seydoux J, Dulloo AG, et al. Modulation of obese gene expression in rat brown and white adipose tissues. FEBS Lett 1995;373:131-4.

21. Dessolin S, Schalling M, Champigny O, Lonnqvist F, Ailhaud G, Dani C, et al. Leptin gene is expressed in rat brown adipose tissue at birth. FASEB J 1997;11:382-7.

22. Cancello R, Zingaretti MC, Sarzani R, Ricquier D, Cinti S. Leptin and UCP1 genes are reciprocally regulated in brown adipose tissue. Endocrinology 1998;139:4747-50.

23. Fei H, Okano HJ, Li C, Lee GH, Zhao C, Darnell R, et al. Anatomic localization of alternatively spliced leptin receptors (Ob-R) in mouse brain and other tissues. Proc Natl Acad Sci USA 1997;94:7001-5.

24. Bray GA. Obesity. In: Fauci AS, Braunwald E, Isselbacher KJ, Wilson JD, Martin JB, Kasper DL, et al., editors. Harrison's principles of internal medicine. 14th ed. New York: McGrawHill Companies, Inc.; 1998. p. 454-62.

25. Ginsberg HN, Goldberg IJ. Disorders of lipoprotein metabolism. In: Fauci AS, Braunwald E, Isselbacher KJ, Wilson JD, Martin JB, Kasper DL, et al., editors. Harrison's principles of internal medicine. 14th ed. New York: McGraw-Hill Companies, Inc.; 1998. p. 2138-49.

26. Hsu SM, Raine L, Fanger H. Use of avidin-biotin-peroxidase complex $(\mathrm{ABC})$ in immunoperoxidase technique: a comparison between $\mathrm{ABC}$ and unlabeled (PAP) procedures. J Histochem 1980;29:577-80.

27. Jin L, Burguera BG, Couce ME, Scheithauer BW, Lamsan J, Eberhardt NL, et al. Leptin and leptin receptor expression in normal and neoplastic human pituitary: evidence of a regulatory role for leptin on pituitary cell proliferation. J Clin Endocrinol Metab 1999;84:2903-11.

28. Qian X, Jin L, Grande JP, Lloyd RV. Transforming growth factor-beta and p27 expression in pituitary cells. Endocrinology 1996;137:3051-60.

29. Maffei M, Halaas J, Ravussin E, Pratley RE, Lee GH, Zhang Y, et al. Leptin levels in human and rodent: measurement of plasma leptin and ob RNA in obese and weight-reduced subjects. Nat Med 1995;1:1155-61.

30. Banks WA, Kastin AJ, Huang W, Jaspan JB, Maness LM. Leptin enters the brain by a saturable system independent of insulin. Peptides 1996;17:305-11.

31. Koistinen HA, Karonen SL, Iivanainen M, Koivisto VA. Circulating leptin has saturable transport into intrathecal space in humans. Eur J Clin Invest 1998;28:894-7.

32. Vaisse C, Halaas JL, Horvath CM, Darnell JE, Jr, Stoffel M, Friedman JM. Leptin activation of Stat3 in the hypothalamus of wild-type and ob/ob mice but not $\mathrm{db} / \mathrm{db}$ mice. Nat Genet 1996;14:95-7.

33. Cinti S, Frederich RC, Zingaretti MC, De Matteis R, Flier JS, Lowell BB. Immunohistochemical localization of leptin and uncoupling protein in white and brown adipose tissue. Endocrinology 1997;138:797-804.

34. Trayhurn P, Thomas ME, Duncan JS, Rayner DV. Effects of fasting and refeeding on ob gene expression in white adipose tissue of lean and obese (ob/ob) mice. FEBS Lett 1995;368: 488-90.

35. Frederich RC, Lollmann B, Hamann A, Napolitano-Rosen A, Kahn BB, Lowell BB, et al. Expression of ob mRNA and its encoded protein in rodents. Impact of nutrition and obesity. J Clin Invest 1995;96:1658-63.

36. Siegrist-Kaiser CA, Pauli V, Juge-Aubry CE, Boss O, Pernin A, Chin WW, et al. Direct effects of leptin on brown and white adipose tissue. J Clin Invest 1997;100:2858-64.

37. Enzinger F, Weiss S. Soft tissue tumors. 3rd ed. St Louis: Mosby-Year Book, Inc.; 1995.

38. Wells HG. Adipose tissue, a neglected subject. J Am Med Assoc 1940;114:2177-83.

39. Schwenzer K, Kang ES. Hormone responsiveness of the lipoma: a tumor of adipose tissue. Horm Metab Res 1980;12:444-9.

40. Atkinson JNC, Galton DJ, Gilbert C. Regulatory defect of glycolysis in human lipomata. Br Med J 1974;1:101-2.

41. Gomez-Capilla JA, Amaya F, Lopez-Cantarero M, Fernandez-Fernandez JM. Effect of insulin and carbenoxolone on adrenaline stimulated lipolysis in human lipoma. Horm Metab Res 1990;22:551-2. 